\title{
Synergistic apoptotic effects of silibinin in enhancing paclitaxel toxicity in human gastric cancer cell lines
}

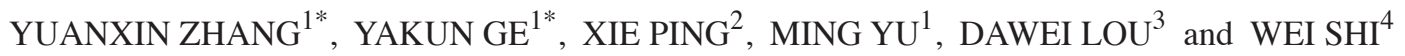 \\ ${ }^{1}$ College of Biology and Food Engineering, Jilin Institute of Chemical Technology, Jilin City, Jilin 132022; \\ ${ }^{2}$ Jilin Entry-Exit Inspection and Quarantine Bureau, Changchun, Jilin 130062; ${ }^{3}$ School of Chemistry and \\ Pharmaceutical Engineering, Jilin Institute of Chemical Technology, Jilin City, Jilin 132022; \\ ${ }^{4}$ Key Laboratory for Molecular Enzymology and Engineering of The Ministry of Education, \\ School of Life Science, Jilin University, Changchun, Jilin 130012, P.R. China
}

Received February 23, 2017; Accepted April 23, 2018

DOI: $10.3892 / \mathrm{mmr} .2018 .9129$

\begin{abstract}
Gastric cancer (GC) is the 3rd leading cause of tumor-associated mortality worldwide. The efficacy of paclitaxel, a frequently used GC chemotherapeutic agent, is hindered due to drug resistance, dose-induced toxicity and adverse side effects. Silibinin, an active compound of a widely consumed dietary supplement, milk thistle extract, has recently been demonstrated to have strong antitumor efficacy in a human GC cell model. Thus, to enhance the efficacy of GC treatment, the present study evaluated whether silibinin exerted a synergistic therapeutic effect with paclitaxel. It was observed that the combination of silibinin-paclitaxel was able to trigger cell cycle arrest and apoptosis. The cell cycle arrest assay indicated that silibinin and paclitaxel alone induced a G2/M phase arrest, and the silibinin-paclitaxel combination strongly inhibited $\mathrm{G} 2 / \mathrm{M}$ cells from entering the $\mathrm{S}$ phase. The apoptosis assay and western blot analysis of poly-ADP-ribose polymerase, pro-caspase 3 and pro-caspase 8 demonstrated that silibinin synergized with paclitaxel in promoting SGC-7901 GC cell apoptosis. Furthermore, upregulation of the ratio of apoptosis regulator $\mathrm{Bcl}-2 /$ apoptosis regulator $\mathrm{BAX}$ and tumor necrosis factor receptor superfamily member 6 (Fas)/Fas ligand indicated that the silibinin-paclitaxel combination
\end{abstract}

Correspondence to: Professor Dawei Lou, School of Chemistry and Pharmaceutical Engineering, Jilin Institute of Chemical Technology, 45 Chengde Street, Jilin City, Jilin 132022, P.R. China E-mail: 1054100603@qq.com

Professor Wei Shi, Key Laboratory For Molecular Enzymology and Engineering of The Ministry of Education, School of Life Science, Jilin University, 2699 Qianjin Street, Changchun, Jilin 130012, P.R. China

E-mail: shiw@jlu.edu.cn

${ }^{*}$ Contributed equally

Key words: silibinin, paclitaxel, apoptosis, gastric cancer, combination chemotherapy, synergism activated the death receptor-mediated pathway in SGC-7901 cells. The results of the present study suggested that silibinin enhanced the therapeutic potential of paclitaxel against human GC SGC-7901 cells.

\section{Introduction}

Gastric cancer (GC) is the 3rd leading cause of tumor-associated mortality worldwide, responsible for 750,000 mortalities in 2012 (1). A total of $\sim 1$ million cases of GC occur worldwide each year, placing it among the types of cancer with the highest incidence in Eastern Europe, Eastern Asia and South Africa $(2,3)$. Complete surgical resection of malignant tumor tissue remains the most common method of treating patients with early GC. Furthermore, since GC frequently causes no clinical symptoms in the earlier stages, numerous patients are at an advanced stage at diagnosis and the tumor is no longer amenable to curative surgical treatment (4). In this setting, chemotherapy may improve and prolong survival in these patients (5), although the benefit must be evaluated against treatment-associated toxicity. 5-fluorouracil (5-FU) is the most important and widely used GC chemotherapy single agent (5). Other single agents, including cisplatin and anthracyclines, have been applied previously $(6,7)$. Furthermore, phase III trials have been undertaken to evaluate docetaxel, and irinotecan, and even oxaliplatin has been clinically used (5). Since GC is a highly heterogeneous disease characterized by multiple histological subtypes and molecular mechanisms, the 5 -FU alone response rate is $\sim 20 \%$ (8). However, the majority of patients who are sensitive to initial chemotherapy eventually fail to react to further cytotoxic chemotherapeutic agents. Thus, a combination therapy regimen has become the accepted standard and has been used as a reference treatment in Europe and the USA (9). Therefore, phytotherapeutic agents (resveratrol, lycopene, sulforaphane, pomegranate and green tea), characterized by high antitumor efficacy and minimal toxicity to normal cells, are potential candidates to be used for their synergistic efficacy in combination with antitumor drugs (10-13).

Silibinin $\left(\mathrm{C}_{25} \mathrm{H}_{22} \mathrm{O}_{10}\right)$ is isolated from the seeds of Silybum marianum (L.) Gaertn (family Asteraceae), which is 
additionally termed milk thistle (14). It has been reported that silibinin has demonstrated pleiotropic anticancer efficacy in various human malignant tumors, including colon, prostate, bladder and skin cancer $(15,16)$. Silibinin is used as a therapeutic agent, in addition to as a sensitizer. Previous studies have reported a synergistic apoptotic effect of a silibinin-doxorubicin/paclitaxel combination in multidrug-resistant colon cancer cells, or a silibinin-cisplatin combination in human prostate carcinoma DU145 cells $(17,18)$. However, there are no reports on the synergistic effect of paclitaxel-silibinin in $\mathrm{GC}$, which is considered to be an important component in the development of a new combination chemotherapy strategy.

The present study evaluated whether silibinin was able to synergize with the therapeutic efficacy of paclitaxel in human GC cell models. The results demonstrated that silibinin promoted paclitaxel-induced growth inhibition, G2/M cell cycle arrest and apoptosis in human GC SGC-7901 cells. The present study provided a deeper insight into the synergistic efficacy of silibinin in combination with paclitaxel in human GC cells.

\section{Materials and methods}

Reagents and drugs. The antibodies for cyclin B1 (cat. no. sc-245), M-phase inducer phosphatase 3 (Cdc25C; cat. no. sc-327), cyclin-dependent kinase 1 (Cdc2; cat. no. sc-54), caspase-3 (cat. no. sc-56053), caspase-8 (cat. no. sc-81656), caspase-9 (cat. no. sc-133109), poly-ADP-ribose polymerase (PARP; cat. no. sc-56196), apoptosis regulator BAX (Bax; cat. no. sc-7480), apoptosis regulator Bcl-2 (Bcl-2; cat. no. sc-7382), tumor necrosis factor receptor superfamily member 6 (Fas; cat. no. sc-8009), Fas ligand (Fas L; cat. no. sc-19681), $\beta$-actin (cat. no. sc-8432) and horseradish peroxidase-labeled goat anti-mouse immunoglobulin G (cat. no. sc-2039) were obtained from Santa Cruz Biotechnology, Inc. (Dallas, TX, USA). The Annexin V-Fluorescein Isothiocyanate (FITC) Apoptosis Detection kit I was obtained from BioTeke Corporation (Beijing, China). Caspase activity assay kits were purchased from Bestbio Company (Shanghai, China). MTT, propidium iodide (PI), silibinin, paclitaxel and all other chemicals used in the present study were obtained from Sigma-Aldrich (Merck KGaA, Darmstadt, Germany).

Cell culture. Human GC cell lines BGC-823, SGC-7901 and AGS were obtained from the Type Culture Collection of the Chinese Academy of Sciences (Shanghai, China) and cultured in Dulbecco's modified Eagle's medium supplemented with $10 \%(\mathrm{v} / \mathrm{v})$ fetal bovine serum and $1 \%$ penicillin/streptomycin, at $37^{\circ} \mathrm{C}$ in a humidified atmosphere with $5 \% \mathrm{CO}_{2} . \mathrm{BGC}-823$, SGC-7901 and AGS cells were used for MTT assays and SGC-7901 cells were used as the cell model for subsequent experiments.

Cell viability assays. Cells $\left(5 \times 10^{3}\right.$ cells/well; SGC-7901, BGC-823 and AGS) were seeded in 96-well plates and grown overnight. The cells were subsequently challenged with either dimethyl sulfoxide (DMSO alone), various doses of silibinin (0, $6.25,12.5,25,50,100,200,400$ or $800 \mu \mathrm{M})$ dissolved in DMSO, paclitaxel $(0.00001,0.001,0.01,0.1,1,10,100$ or $1,000 \mathrm{nM})$ alone, or silibinin $(25$ or $50 \mu \mathrm{M})$ combined with different concentrations of paclitaxel $(0.001,0.01,0.1,1$ or $10 \mathrm{nM})$ for $48 \mathrm{~h}$. Following treatment for $48 \mathrm{~h}, 5 \mathrm{mg} / \mathrm{ml}$ MTT reagent was added into the culture medium and the cells were incubated for $4 \mathrm{~h}$. Thereafter, the medium with MTT was removed and $150 \mu 1$ DMSO was added to dissolve the formazan crystals. Living cell absorbance was spectrophotometrically measured at a wavelength of $490 \mathrm{~nm}$, according to the reduction of yellow tetrazolium MTT to an intracellular purple formazan. The combinational growth-inhibitory effect was calculated using the combination index (CI)/isobologram method (19). The assay was repeated in triplicate to confirm accuracy.

Determination of CI. CI represents a quantitative conception of synergism and antagonism and was calculated by the Chou-Talalay equation (19):

$$
\mathrm{CI}=\frac{(D)_{S}}{\left(D_{x}\right)_{S}}+\frac{(D)_{P}}{\left(D_{x}\right)_{P}}=\frac{(D)_{S}}{\left(D_{m}\right)_{S}\left[f_{a} /\left(1-f_{a}\right)\right]^{1 / m_{1}}}+\frac{(D)_{P}}{\left(D_{m}\right)_{P}\left[f_{a} /\left(1-f_{a}\right)\right]^{1 / m_{2}}}
$$

Where $\mathrm{CI}<1,=1,>1$ represents synergism, additive effect, and antagonism in drugs combination and In the denominators $\left(D_{x}\right)_{s}$ and $\left(D_{x}\right)_{p}$ are the concentration of single $\left(D_{x}\right)_{s}(\mathrm{~S}$, silibinin $)$ and $\left(D_{x}\right)_{p}(\mathrm{P}$, paclitaxel) that causes $x \%$ inhibition, whereas the numerators $(D)_{\mathrm{s}}$ and $(D)_{\mathrm{p}}$ are the concentration of $D_{s}$ and $D_{p}$ in silibinin-paclitaxel combination at $x \%$ inhibition setting. The $\left(D_{x}\right)_{s}$ and $\left(D_{x}\right)_{p}$ were calculated based on the meridian-effect equation of Chou et al (20):

$$
D_{x}=\left(D_{m}\right)\left[f_{a} /\left(1-f_{a}\right)\right]^{1 / m}
$$

Where $D_{x}$ is the median-effect dose obtained from anti-log of the X-intercept of the median-effect plot, X-log $(D)$ vs., $\left.Y=\log \left[f_{a} / 1-f_{a}\right)\right]$, or, $\mathrm{D}_{\mathrm{m}}=10_{-}{ }^{(Y \text {-intercept }) / m}$, is the fraction affected by the dose $D$, and $m$ is the slope of the median-effect plot.

Flow cytometry assay. To examine cell cycle arrest and apoptosis $(21,22)$, the cells $\left(4 \times 10^{5}\right)$ were plated in a 6 -well plate containing $2 \mathrm{ml}$ medium and incubated overnight at $37^{\circ} \mathrm{C}$. Medium was removed and replaced with fresh culture medium containing silibinin $(25 \mu \mathrm{M})$ alone, or paclitaxel $(10 \mathrm{nM})$ alone, or silibinin $(25 \mu \mathrm{M})$ in combination with $10 \mathrm{nM}$ paclitaxel, and the cells were incubated for $24 \mathrm{~h}$ at $37^{\circ} \mathrm{C}$. Control cells were treated only with DMSO. Following $24 \mathrm{~h}$ of treatment, the cells were collected and washed twice with cold PBS (0.01 M; pH 7.4). The cells were subsequently fixed in ice-cold $70 \%$ ethanol overnight at $4^{\circ} \mathrm{C}$, washed twice with cold PBS (0.01 M; pH 7.4), and stained with $0.5 \mathrm{ml}$ cold PI solution containing $10 \mu \mathrm{l}$ RNase A $(25 \mu \mathrm{g} / \mathrm{ml})$ and $10 \mu \mathrm{PI}(50 \mu \mathrm{g} / \mathrm{ml})$ at $37^{\circ} \mathrm{C}$ for $30 \mathrm{~min}$ in the dark for cell cycle analysis. To assess the status of apoptosis, the cells $\left(10^{6}\right)$ following treatment for $24 \mathrm{~h}$ were collected and stained with Annexin-V-FITC/PI according to the manufacturer's protocol. The cells were analyzed on a flow cytometer (BD FACSCalibur $^{\mathrm{TM}}$; BD Biosciences, Franklin Lakes, NJ, USA) and data acquisition and analysis were performed using FlowJo software version 7.6 (Tree Star, Inc., Ashland, OR, USA). All the experiments were performed in triplicate.

Western blotting. The method of total protein extraction was performed as described previously (23). The cells $\left(2 \times 10^{6}\right)$ were plated in $100 \mathrm{~mm}$ dishes. Following treatment with silibinin 
Table I. Combination index values of silibinin-paclitaxel combinations in different gastric cancer cell lines.

\begin{tabular}{|c|c|c|c|c|c|c|}
\hline \multirow[b]{3}{*}{ Drug treatment } & \multicolumn{6}{|c|}{ Cell line } \\
\hline & \multicolumn{2}{|c|}{ SGC-7901 } & \multicolumn{2}{|c|}{ AGS } & \multicolumn{2}{|c|}{ BGC-823 } \\
\hline & Sil, $25 \mu \mathrm{M}$ & Sil, $50 \mu \mathrm{M}$ & Sil, $25 \mu \mathrm{M}$ & Sil, $50 \mu \mathrm{M}$ & Sil, $25 \mu \mathrm{M}$ & Sil, $50 \mu \mathrm{M}$ \\
\hline Pac, $0.001 \mathrm{nM}$ & 0.111 & 0.1 & 0.091 & 0.123 & 0.176 & 0.136 \\
\hline Pac, $0.01 \mathrm{nM}$ & 0.151 & 0.141 & 0.062 & 0.083 & 0.269 & 0.267 \\
\hline Pac, $0.1 \mathrm{nM}$ & 0.212 & 0.175 & 0.104 & 0.116 & 0.177 & 0.173 \\
\hline Pac, $1 \mathrm{nM}$ & 0.267 & 0.231 & 0.046 & 0.054 & 0.418 & 0.423 \\
\hline Pac, $10 \mathrm{nM}$ & 0.302 & 0.258 & 0.104 & 0.132 & 0.905 & 0.95 \\
\hline
\end{tabular}

Sil, silibinin; Pac, paclitaxel.

or paclitaxel alone, or the silibinin-paclitaxel combination, the cells were collected, washed twice with ice-cold PBS and lysed in ice-cold cell lysis buffer [50 mmol/1 Tris ( $\mathrm{pH} 8.0$ ), $150 \mathrm{mmol} / 1 \mathrm{NaCl}, 0.1 \% \mathrm{SDS}, 1 \% \mathrm{NP} 40$, and $0.5 \%$ sodium deoxycholate)] containing proteinase inhibitors ( $1 \%$ cocktail and $1 \mathrm{mmol} / 1$ phenylmethane sulfonyl fluoride) for $30 \mathrm{~min}$. Protein concentration was determined via the Bradford assay. Proteins samples $(40 \mu \mathrm{g})$ were denatured in $5 \mathrm{X}$ sample buffer at $100^{\circ} \mathrm{C}$ for $5 \mathrm{~min}$ and separated on $12 \%$ SDS-PAGE gels. The proteins on the gels were transferred to polyvinylidene difluoride membranes for $2 \mathrm{~h}$ at $60 \mathrm{~V}$. The membranes were blocked with $5 \%$ non-fat milk at $37^{\circ} \mathrm{C}$ for $1 \mathrm{~h}$ and incubated overnight at $4^{\circ} \mathrm{C}$ with specific primary antibodies (dilution, 1:500). The membranes were subsequently incubated with goat anti-mouse IgG horseradish peroxidase-conjugated secondary antibodies at room temperature for $1 \mathrm{~h}$ (dilution, 1:2,000). To quantify the results of the western blotting, the image of the western blot on the PVDF membrane was scanned into a .jpg image file and the alterations in band gray levels were analyzed using ImageJ 1.51k (National Institutes of Health, Bethesda, MD, USA). The size of the gray level value represents the protein expression level.

Caspase activity. Caspase activity assays were performed according to the manufacturer's instructions. In brief, cells were collected following treatment and were centrifuged $\left(10,000 \times \mathrm{g} ; 5 \mathrm{~min} ; 4^{\circ} \mathrm{C}\right)$ in ice-cold $\mathrm{PBS}$, according to the manufacturer's protocol. Subsequently, the cells were lysed in $100 \mu \mathrm{l}$ lysis buffer and the supernatant was collected via centrifugation $\left(10,000 \mathrm{x} \mathrm{g} ; 10 \mathrm{~min} ; 4^{\circ} \mathrm{C}\right)$. A total of $10 \mu \mathrm{l}$ cell lysate protein was diluted in $80 \mu \mathrm{l}$ reaction buffer containing $10 \mu \mathrm{l}$ caspase-3 substrate (Ac-DEVD-pNA; $2 \mathrm{mM}$ ), caspase 8 substrate (Ac-IETD-pNA; $2 \mathrm{mM}$ ) or caspase-9 substrate (Ac-LEHD-pNA; $2 \mathrm{mM}$ ) with $1 \mu \mathrm{l}$ dithiothreitol, and was incubated at $37^{\circ} \mathrm{C}$ for $60 \mathrm{~min}$. The caspase activity was measured using a microplate reader at $405 \mathrm{~nm}$.

Statistical analysis. All data are presented as the mean \pm standard error of the mean of three independent experiments. Statistical differences were evaluated by one-way analysis of variance. SPSS 19.0 software (IBM Corp., Armonk, NY, USA) was used for statistical analysis. $\mathrm{P}<0.05$ was considered to indicate a statistically significant difference.

\section{Results}

Synergistic effects of the silibinin-paclitaxel combination on $S G C-7901$ cell growth inhibition. To assess the inhibitory effect of the silibinin-paclitaxel combination, the effect of silibinin or paclitaxel alone was tested on three GC cell lines: SGC-7901, BGC-823 and AGS. Following treatment with silibinin or paclitaxel for $48 \mathrm{~h}$, cell proliferation in all three cell lines was inhibited by silibinin (Fig. 1A). The half-maximal inhibitory concentration $\left(\mathrm{IC}_{50}\right)$ values for silibinin in SGC-7901, BGC-823 and AGS cells were 69.09, 201.69 and $122.83 \mu \mathrm{M}$, respectively (data not shown), suggesting that silibinin had a broad spectrum growth inhibitory effect on various differentiated GC cell lines. In addition, all three GC cell lines were sensitive to paclitaxel (Fig. 1B); the $\mathrm{IC}_{50}$ values of SGC-7901, BGC-823 and AGS were 6.01, 59.22 and $566.49 \mathrm{nM}$, respectively (data not shown). Therefore, treatment with these agents was able to inhibit GC cell line growth in a dose-dependent manner.

Based on the $\mathrm{IC}_{50}$ values for silibinin or paclitaxel alone applied to the three GC cell lines, silibinin $(25$ or $50 \mu \mathrm{M})$ was combined with various doses of paclitaxel $(0.001,0.01,0.1,1$ and $10 \mathrm{nM}$ ) to investigate their potential synergism in GC cell lines. A silibinin-paclitaxel combination led to decreased $\mathrm{IC}_{50}$ values of $0.025,10.83$ and $0.17 \mathrm{nM}$ (based on the concentration of paclitaxel) for SGC-7901, BGC-823 and AGS, respectively, as presented in Fig. 1C. The CI values of free silibinin (25 or $50 \mu \mathrm{M})$-paclitaxel $(0.001,0.01,0.1,1$ or $10 \mathrm{nM})$ in $\mathrm{GC}$ cell lines are summarized in Table I, and indicated that silibinin and paclitaxel exhibited strong synergism in all three cell lines. Furthermore, the inhibitory effect of the silibinin-paclitaxel combination was notably increased compared with the single treatments, indicating that the silibinin may be used to effectively reduce the dosage of paclitaxel in cancer chemotherapy. SGC-7901 cells were used for further studies due to their increased sensitivity to the combination treatment.

Effect of the silibinin-paclitaxel combination on the cell cycle arrest of SGC-7901 cells. On the basis of the synergistic growth inhibition effect of the silibinin-paclitaxel combination in SGC-7901 cells, the present study assessed whether the inhibition involved an alteration in cell cycle arrest by these combinations compared with a single agent. As presented in Fig. 2A and B, treatment of cells with $25 \mu \mathrm{M}$ silibinin alone led to an increased 

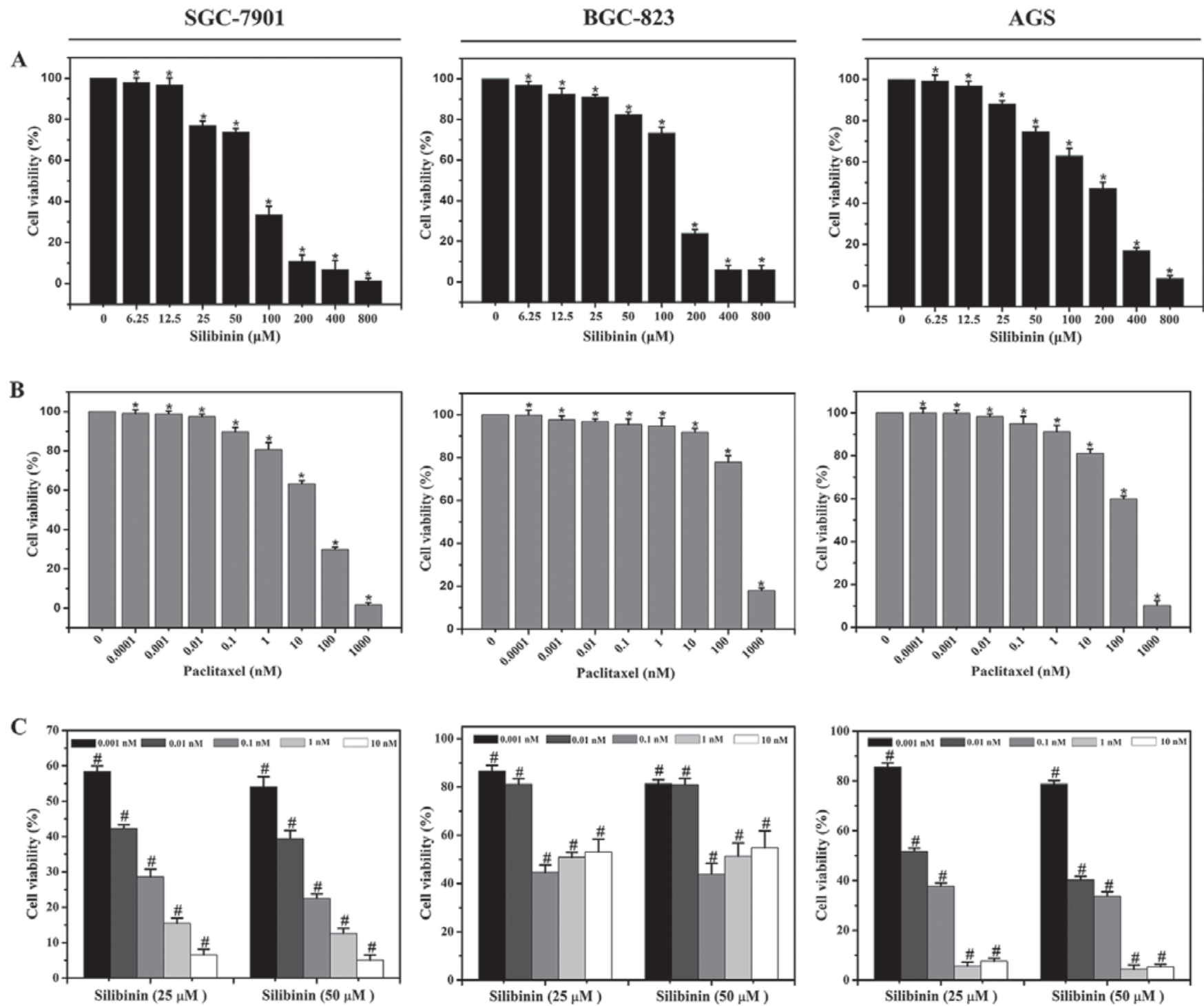

Figure 1. Growth inhibition effect of silibinin and paclitaxel alone, or a silibinin-paclitaxel combination, on gastric cancer cell lines. Cells (SGC-7901, BGC-823 and AGS) were incubated in Dulbecco's modified Eagle's medium supplemented with $10 \%$ fetal bovine serum for $24 \mathrm{~h}$ and treated with the indicated concentrations of (A) silibinin, or (B) paclitaxel alone, or (C) treated with silibinin $(25$ or $50 \mu \mathrm{M})$ in combination with paclitaxel $(0.001,0.01,0.1,1$ or $10 \mathrm{nM})$ for $48 \mathrm{~h}$, respectively. Cell viability was determined by an MTT assay. ${ }^{*} \mathrm{P}<0.05$ vs. control; ${ }^{*} \mathrm{P}<0.05$ vs. same concentration of silibinin or paclitaxel.

percentage in the G2/M phase compared with the control (from $25.11 \pm 2.87$ to $46.89 \pm 5.02 \%$ ), and $10 \mathrm{nM}$ paclitaxel raised the percentage of cells in the $\mathrm{G} 2 / \mathrm{M}$ phase compared with the control (from $25.11 \pm 2.87$ to $38.65 \pm 1.97 \%$ ) following $24 \mathrm{~h}$ of treatment. The silibinin $(25 \mu \mathrm{M})$-paclitaxel $(10 \mathrm{nM})$ combination increased the ratio of $\mathrm{G} 2 / \mathrm{M}$ phase cells (from $25.11 \pm 2.87$ to $96.62 \pm 4.85 \%$ ) in addition to reducing the number of G1 and S phase cells. These data suggested that the drug combination blocked SGC-7901 cells at the $\mathrm{G} 2 / \mathrm{M}$ phase and prevented entry into the $\mathrm{M}$ phase.

Due to the synergistic effects of the silibinin-paclitaxel combination on G2/M arrest, the molecular events associated with the combinatorial effect on $\mathrm{G} 2 / \mathrm{M}$ phase arrest in SGC-7901 cells were investigated. Using western blot analysis, it was observed that the expression levels of $\mathrm{Cdc} 2$ and $\mathrm{Cdc} 25 \mathrm{C}$ were notably decreased following combination treatment with silibinin-paclitaxel, which indicated a downregulation of the Cdc25C-cyclin B1-Cdc2 pathway could be the possible molecular mechanism of silibinin-paclitaxel efficacy on cell cycle arrest in SGC-7901 cells (Fig. 2C).
Apoptotic effect of silibinin-paclitaxel combination on $S G C-7901$ cells. It was subsequently assessed whether treatment with a combination of silibinin $(25 \mu \mathrm{M})$ and paclitaxel $(10 \mathrm{nM})$ was accompanied by increased apoptosis. As presented in Fig. 3A, treatment of cells with silibinin $(25 \mu \mathrm{M})-10 \mathrm{nM}$ paclitaxel for $24 \mathrm{~h}$ exerted a significant apoptotic effect compared with silibinin $(25 \mu \mathrm{M})$ or $10 \mathrm{nM}$ paclitaxel alone, or DMSO. The quantitative data demonstrated that DMSO, silibinin $(25 \mu \mathrm{M})$ or $10 \mathrm{nM}$ paclitaxel alone produced $5.82 \pm 1.29 \%$, $10.59 \pm 1.53 \%$ and $24.96 \pm 1.25 \%$ apoptotic cells, respectively, while the combination led to a significant increase in apoptosis accounting for $88.14 \pm 4.4 \%$ apoptotic cells (Fig. 3B).

Silibinin-paclitaxel combination activates the death receptor-mediated pathway in SGC-7901 cells. To elucidate the molecular mechanism of silibinin-paclitaxel combination-mediated apoptosis, the expression levels of pro-caspase 3, pro-caspase 8 and pro-caspase 9, and PARP cleavage, were studied. When SGC-7901 cells were treated with the silibinin 
A
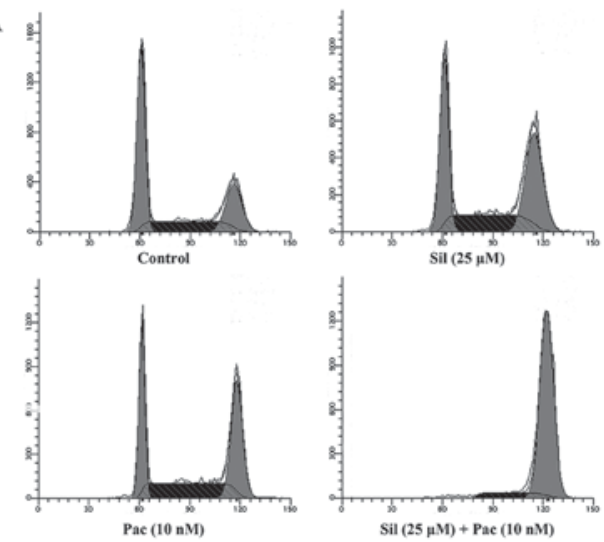

B

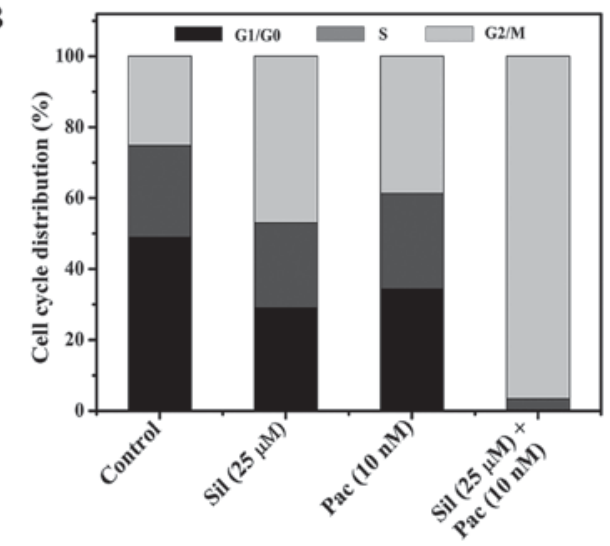

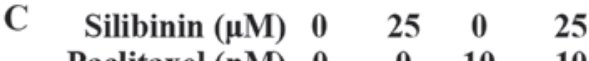

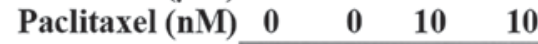

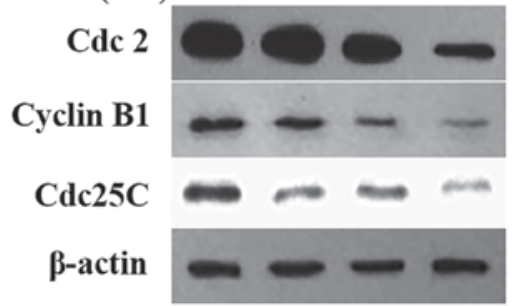

Figure 2. Combinatorial effect of silibinin and paclitaxel on cell-cycle distribution in human gastric cancer SGC-7901 cells. SGC-7901 cells were treated with either dimethyl sulfoxide as a control, $25 \mu \mathrm{M}$ silibinin, $10 \mathrm{nM}$ paclitaxel, or a $25 \mu \mathrm{M}$ silibinin- $10 \mathrm{nM}$ paclitaxel combination for $24 \mathrm{~h}$. At the end of these treatments, adherent and non-adherent cells were collected and incubated overnight with $70 \%$ ethanol at $4^{\circ} \mathrm{C}$. The DNA content of SGC-7901 cells was analyzed using a flow cytometer. (A) Cell cycle distribution, and (B) the percentages of cells in the G1, S and G2/M phases are presented. (C) The protein expression of $\mathrm{Cdc} 2$, cyclin $\mathrm{B} 1$ and $\mathrm{Cdc} 25 \mathrm{C}$ was visualized using western blotting. $\beta$-actin was used as an internal control. Sil, silibinin; Pac, paclitaxel; Cdc2, cyclin-dependent kinase 1; Cdc25C, M-phase inducer phosphatase 3.

and paclitaxel combination for $24 \mathrm{~h}$, pro-caspase 3 expression was reduced and the level of cleaved caspase 3 was increased (Fig. 4A). Furthermore, the caspase 3 activity assay illustrated a trend of gradually increasing activity by 5.9 -fold (compared with the control), as assessed by colorimetry (Fig. 4B). Since PARP is a reliable marker of apoptosis and a substrate for caspase activity, the cleavage level of PARP was assessed. As presented in Fig. 4A, the silibinin-paclitaxel combination led to increased PARP cleavage compared with silibinin or paclitaxel alone. Moreover, the silibinin-paclitaxel combination downregulated the expression level of pro-caspase 8 , increased caspase 8 activity and triggered the cleavage of pro-caspase 8 , which
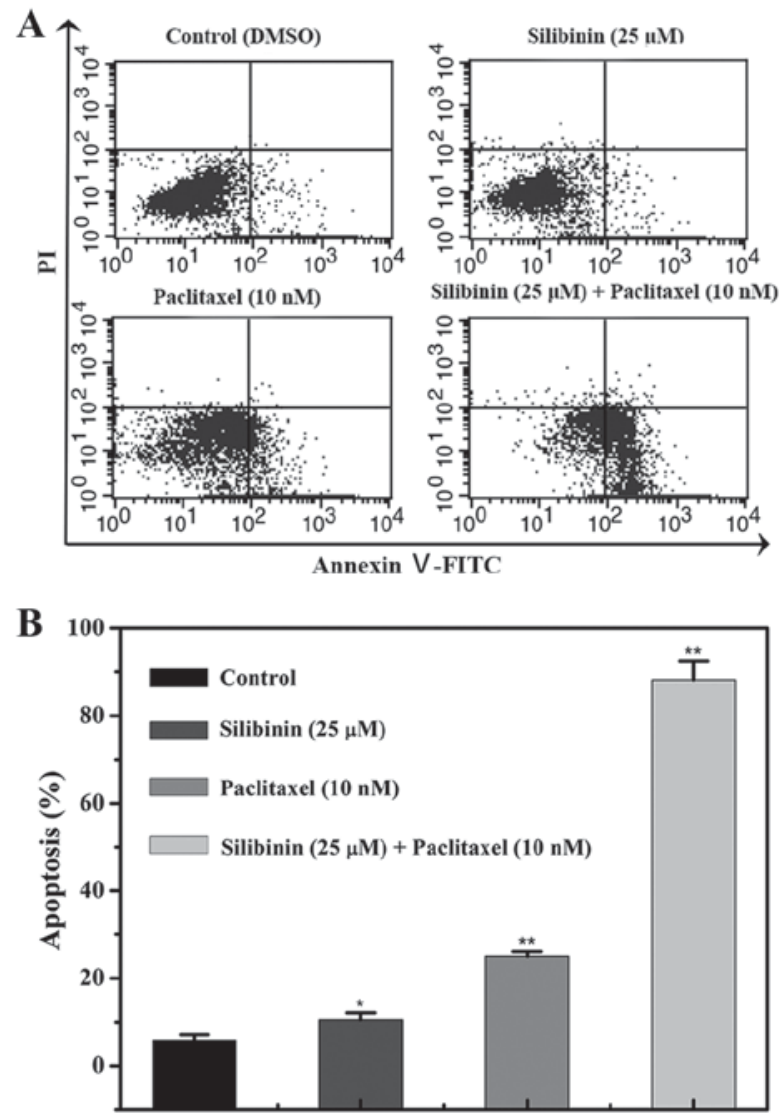

Figure 3. Silibinin in combination with paclitaxel significantly induces cellular apoptosis in SGC-7901 cells. (A) Cells treated with either the DMSO control or silibinin $(25 \mu \mathrm{M})$ in combination with $10 \mathrm{nM}$ paclitaxel for $24 \mathrm{~h}$ were assessed for apoptosis by staining with Annexin V-FITC and PI. (B) The data of apoptotic cell percentages are expressed as the mean \pm standard error of the mean of at least three independent experiments. ${ }^{*} \mathrm{P}<0.05$, ${ }^{* * *} \mathrm{P}<0.01$ vs. control. FITC, fluorescein isothiocyanate; PI, propidium iodide; DMSO, dimethyl sulfoxide.

suggested that caspase 8 was activated. Activation of caspase 8 requires internal proteolysis at aspartic residues to generate a heterodimeric enzyme, Fas-associated death domain protein (FADD)-caspase 8 . This proteolytic processing is involved in the apoptosis induced by Fas/Fas L and various apoptotic stimuli. Within the Fas-FADD-caspase 8 complex, caspase 8 undergoes self-cleavage to convert to its active forms $(24,25)$. As presented in Fig. 4A, the silibinin-paclitaxel combination increased the expression levels of Fas and Fas L post-treatment.

In addition, Bax (pro-apoptotic protein) and $\mathrm{Bcl}-2$ (anti-apoptotic protein) serve an important role in the regulation of apoptosis. Therefore, alteration in the Bcl-2/Bax expression is an important determinant of apoptosis. As presented in Fig. 4A, the intracellular expression level of Bcl-2 decreased in the silibinin-paclitaxel combination-treated group compared with the control or single treatment groups. Furthermore, the intracellular expression level of Bax increased in the silibinin-paclitaxel combination-treated group compared with the control or single treatment groups.

\section{Discussion}

Systemic toxicity and multidrug resistance have become the principal barriers in cancer chemotherapy (21). In this 
A

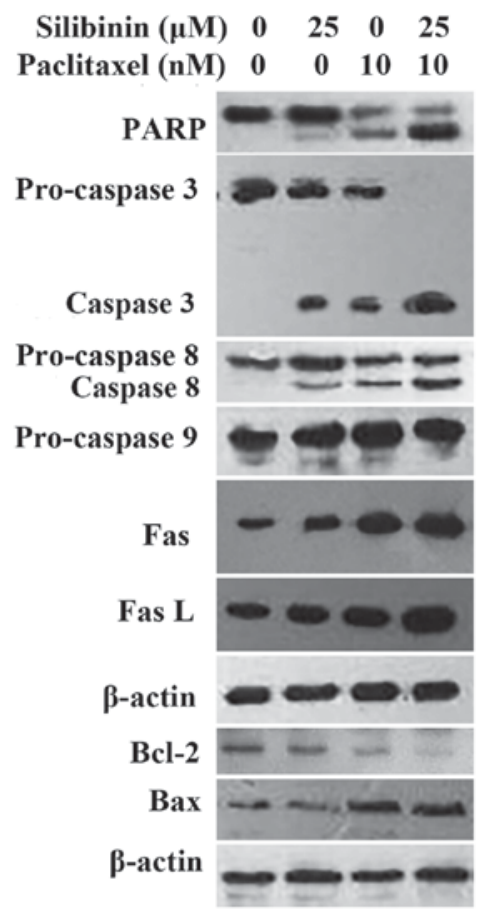

B

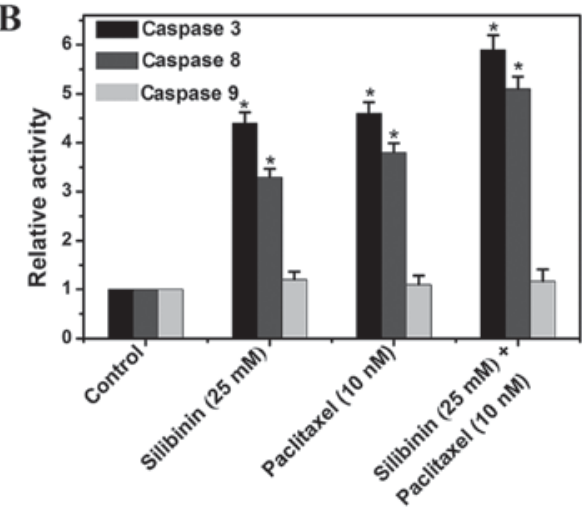

Figure 4. Effects of silibinin and paclitaxel on the expression of proteins associated with apoptosis in SGC-7901 cells. (A) Cells were treated with $25 \mu \mathrm{M}$ silibinin, $10 \mathrm{nM}$ paclitaxel, or the drug combination for $24 \mathrm{~h}$ and were harvested for western blot analysis, and (B) equal amounts of cell lysates were analyzed for caspase- 3 , caspase- 8 and caspase- 9 activity using DEVD-pNA, IETD-pNA and LEHD-pNA as substrates, respectively. "P<0.05 vs. respective control. PARP, poly-ADP-ribose polymerase; Fas, tumor necrosis factor receptor superfamily member 6; Fas L, Fas ligand; Bcl-2, apoptosis regulator $\mathrm{Bcl}-2$; Bax, apoptosis regulator BAX.

regard, there remains a need to develop combination chemotherapy methods using clinical anticancer drugs and natural compounds with a known mechanism of action (26). In the present study, the effect of the silibinin-paclitaxel combination in SGC-7901 cells was investigated. These data indicated that silibinin synergized with the therapeutic effect of paclitaxel in SGC-7901 cells, via the induction of G2/M arrest and apoptosis. The results were significant as GC has frequently not been sensitive to anti-cancer drugs (27).

Cell cycle regulation involves a series of complex events during cell proliferation. Cell cycle regulatory proteins, cyclin-dependent kinases and cyclins, are a primary means of controlling cancer cell division (28). In particular, the Cdc2-cyclin $\mathrm{B} 1$ complex serves an important role in the regulation of the transition between the G2 and M phases (29). In the present study, the silibinin-paclitaxel combination induced $\mathrm{G} 2 / \mathrm{M}$ phase arrest by downregulating the expression levels of $\mathrm{Cdc} 2$ and cyclin $\mathrm{B} 1$.

Apoptosis induced by anticancer drugs involves two principal cell signaling pathways: The mitochondria-mediated pathway and the death receptor-mediated pathway $(30,31)$. These pathways are associated with protease caspases, which are able to cleave regulatory and structural molecules, and induce apoptosis in cancer cells (32). Death receptors (DRs), including Fas, DR4 and tumor necrosis factor receptor, are important regulators of apoptosis. Ligation of DRs leads to the assembly of a death inducing signaling complex that triggers the cleavage of proteins, the activation of caspases and, ultimately, the apoptosis of cancer cells (33). A previous investigation demonstrated that silibinin induces apoptosis and causes cell cycle arrest by downregulating cyclinB1, survivin, Bcl-2 like 1 and induced myeloid leukemia cell differentiation protein Mcl-1, and activating caspase 3 and caspase 9 in MGC803 cells (34). However, in the present study, the percentage of apoptotic cells increased, the expression levels of pro-caspase 3 and 8 were significantly downregulated and the pro-caspase 9 level exhibited no evident change following treatment with silibinin $(25 \mu \mathrm{M})$-paclitaxel $(10 \mathrm{nM})$. These differences in the mechanism of silibinin-induced apoptosis may be due to tumor heterogeneity, which affects tumor cells growth, immunogenicity, metastasis ability and drug sensitivity (35).

Furthermore, the increase in the expression level of Fas/Fas L, alterations in $\mathrm{Bcl}-2 / \mathrm{Bax}$ expression, and activation of caspase 3 and 8 further suggested that the silibinin-paclitaxel combination induced apoptosis via the death receptor-mediated pathway.

In the present study, the primary focus was on the molecular mechanism at the cellular level, and it was demonstrated that the silibinin-paclitaxel combination was able to induce $\mathrm{G} 2 / \mathrm{M}$ arrest by regulating proteins $\mathrm{Cdc} 2$ and cyclin $\mathrm{B} 1$, and apoptosis, through alterations in $\mathrm{Bcl}-2 / \mathrm{Bax}$ expression, and the upregulation of Fas/Fas L expression, and the activity of caspase 3 and 8, proteins in SGC-7901 cells. However, in vivo testing of the combination effect of silibinin-paclitaxel is required to establish the synergistic efficacy of the two drugs for chemotherapy in human GC, using a SGC-7901-bearing $\mathrm{BALB} / \mathrm{c}$ nude mouse model, the results of which may lead to a PhaseI trial in human patients with GC.

In conclusion, the data of the present study demonstrated that a silibinin-paclitaxel combination may be a potent chemotherapeutic strategy that may inhibit SGC-7901 cell proliferation and induce apoptosis, and warrants further study as a combination therapy in human GC.

\section{Acknowledgements}

Not applicable.

\section{Funding}

This study was supported by grants from the Special Foundation for Industry Innovation of Development and Reform Commission of Jilin (grant no. 2018C049-4), the Foundation of Education Department of Jilin Province (grant no. 2016133), the Youth Foundation of Science and Technology Bureau of Jilin City (grant no. 201750259) and the Major Programs of the Jilin Institute of Chemical Technology (grant no. 20180101). 


\section{Availability of data and materials}

All data generated or analyzed during this study are included in this published article.

\section{Authors' contributions}

YZ, DL and WS conceived and designed the experiments. YZ and YG performed the experiments. YZ produced the manuscript. XP and MY conducted data analysis.

\section{Ethics approval and consent to participate}

Not applicable.

\section{Consent for publications}

Not applicable.

\section{Competing interests}

The authors declare that they have no competing interests.

\section{References}

1. Rugge M, Fassan M and Graham DY: Epidemiology of gastric cancer: In: Gastric Cancer. Springer Int. Publ., Switzerland, pp23-34, 2015.

2. Winer E, Gralow J, Diller L, Karlan B, Loehrer P, Pierce L, Demetri G, Ganz P, Kramer B, Kris M, et al: Clinical cancer advances 2008: Major research advances in cancer treatment, prevention, and screening-a report from the American society of clinical oncology. J Clin Oncol 27: 812-826, 2009.

3. Bozzetti F, Marubini E, Bonfanti G, Miceli R, Piano C and Gennari L: Subtotal versus total gastrectomy for gastric cancer: Five-year survival rates in a multicenter randomized Italian trial. Italian gastrointestinal tumor study group. Ann Surg 230: 170-178, 1999.

4. Song H, Zhu J and Lu D: Molecular-targeted first-line therapy for advanced gastric cancer. Cochrane Database Syst Rev 7: CD011461, 2016.

5. Wagner AD, Unverzagt S, Grothe W, Kleber G, Grothey A, Haerting $\mathrm{J}$ and Fleig WE: Chemotherapy for advanced gastric cancer. Cochrane Database Syst Rev: CD004064, 2010.

6. Leichman L and Berry BT: Cisplatin therapy for adenocarcinoma of the stomach. Semin Oncol 18 (1 suppl 3): S25-S33, 1991.

7. Preusser P, Achterrath W, Wilke H, Lenaz L, Fink U, Heinicke A, Meyer J and Bunte H: Chemotherapy of gastric cancer. Cancer Treat Rev 15: 257-277, 1988.

8. Wang K, Yuen ST, Xu J, Lee SP, Yan HH, Shi ST, Siu HC, Deng S, Chu KM, Law S, et al: Whole-genome sequencing and comprehensive molecular profiling identify new driver mutations in gastric cancer. Nat Genet 46: 573-582, 2014.

9. Cunningham D, Starling N, Rao S, Iveson T, Nicolson M, Coxon F, Middleton G, Daniel F, Oates J and Norman AR; Upper Gastrointestinal Clinical Studies Group of the National Cancer Research Institute of the United Kingdom: Capecitabine and oxaliplatin for advanced esophagogastric cancer. New Engl J Med 358: 36-46, 2008.

10. Kelloff GJ: Perspectives on cancer chemoprevention research and drug development. Adv Cancer Res 78: 199-334, 2000.

11. Sporn MB and Suh N: Chemoprevention of cancer. Carcinogenesis 21: 525-530, 2000

12. van Die MD, Bone KM, Emery J, Williams SG, Pirotta MV and Paller CJ: Phytotherapeutic interventions in the management of biochemically recurrent prostate cancer: A systematic review of randomised trials. BJU Int 177 (Suppl 4): S17-S34, 2016.

13. Agarwal R: Cell signaling and regulators of cell cycle as molecular targets for prostate cancer prevention by dietary agents Biochem Pharmacol 60: 1051-1059, 2000.

14. Deep G and Agarwal R: Antimetastatic efficacy of silibinin: Molecular mechanisms and therapeutic potential against cancer. Cancer Metastasis Rev 29: 447-463, 2010.
15. Singh RP, Dhanalakshmi S and Agarwal R: Phytochemicals as cell cycle modulators-a less toxic approach in halting human cancers. Cell Cycle 1: 156-161, 2002.

16. Katiyar SK, Korman NJ, Mukhtar H and Agarwal R: Protective effects of silymarin against photocarcinogenesis in a mouse skin model. J Natl Cancer Inst 89: 556-566, 1997.

17. Colombo V, Lupi M, Falcetta F, Forestieri D, D'Incalci M and Ubezio P: Chemotherapeutic activity of silymarin combined with doxorubicin or paclitaxel in sensitive and multidrug-resistant colon cancer cells. Cancer Chemother Pharmacol 67: 369-379, 2011.

18. Dhanalakshmi S, Agarwal P, Glode LM and Agarwal R: Silibinin sensitizes human prostate carcinoma DU145 cells to cisplatinand carboplatin-induced growth inhibition and apoptotic death. Int J Cancer 106: 699-705, 2003.

19. Chou TC and Talalay P: Analysis of combined drug effects: A new look at a very old problem. Trends Pharmacol Sci 4: 450-454, 1983.

20. Chou TC, Motzer RJ, Tong Y and Bosl GJ: Computerized quantitation of synergism and antagonism of taxol, topotecan, and cisplatin against human teratocarcinoma cell growth: A rational approach to clinical protocol design. J Natl Cancer Inst 86: 1517-1524, 1994

21. Agarwal C, Singh RP, Dhanalakshmi S, Tyagi AK, Tecklenburg M, Sclafani RA and Agarwal R: Silibinin upregulates the expression of cyclin-dependent kinase inhibitors and causes cell cycle arrest and apoptosis in human colon carcinoma HT-29 cells. Oncogene 22: 8271-8282, 2003.

22. Li L, G Y, Zhang L, Zeng J, He D and Sun Y: Silibinin inhibits cell growth and induces apoptosis by caspase activation, down-regulating survivin and blocking EGFR-ERK activation in renal cell carcinoma. Cancer Lett 272: 61-69, 2008.

23. Hogan FS, Krishnegowda NK, Mikhailova $M$ and Kahlenberg MS: Flavonoid, Silibinin, inhibits proliferation and promotes cell-cycle arrest of human colon cancer. J Surg Res 143: 58-65, 2007.

24. Kischkel FC, Hellbardt S, Behrmann I, Germer M, Pawlita M, Krammer PH and Peter ME: Cytotoxicity-dependent APO-1 (Fas/CD95)-associated proteins form a death-inducing signaling complex (DISC) with the receptor. EMBO J 14: 5579-5588, 1995.

25. Kominami K, Nakabayashi J, Nagai T, Tsujimura Y, Chiba K, Kimura H, Miyawaki A, Sawasaki T, Yokota H, Manabe N and Sakamaki K: The molecular mechanism of apoptosis upon caspase-8 activation: Quantitative experimental validation of a mathematical model. Biochim Biophys Acta 1823: 1825-1840, 2012.

26. Figg WD, Arlen P, Gulley J, Fernandez P, Noone M, Fedenko K, Hamilton M, Parker C, Kruger EA, Pluda J and Dahut WL: A randomized Phase II trial of docetaxel (taxotere) plus thalidomide in androgen-independent prostate cancer. Semin Oncol 28 (4 suppl 15): S62-S66, 2001.

27. Scartozzi M, Galizia E, Verdecchia L, Berardi R, Antognoli S, Chiorrini S and Cascinu S: Chemotherapy for advanced gastric cancer: Across the years for a standard of care. Expert Opin Pharmacother 8: 797-808, 2007.

28. Chen YN, Chen JC, Yin SC, Wang GS, Tsauer W, Hsu SF and Hsu SL: Effector mechanisms of norcantharidin-induced mitotic arrest and apoptosis in human hepatoma cells. Int J Cancer 100: $158-165,2002$.

29. Graña X and Reddy EP: Cell cycle control in mammalian cells: Role of cyclins, cyclin dependent kinases (CDKs), growth suppressor genes and cyclin-dependent kinase inhibitors (CKIs). Oncogene 11: 211-219, 1995.

30. Peták I and Houghton JA: Shared pathways: Death receptors and cytotoxic drugs in cancer therapy. Pathol Oncol Res 7: 95-106, 2001.

31. Debatin KM, Poncet D and Kroemer G: Chemotherapy: Targeting the mitochondrial cell death pathway. Oncogene 21: 8786-8803, 2002.

32. Ghobrial IM, Witzig TE and Adjei AA: Targeting apoptosis pathways in cancer therapy. CA Cancer J Clin 55: 178-194, 2005.

33. Galluzzi L, Vitale I, Abrams JM, Alnemri ES, Baehrecke EH, Blagosklonny MV, Dawson TM, Dawson VL, El-Deiry WS, Fulda S, et al: Molecular definitions of cell death subroutines: Recommendations of the nomenclature committee on cell death 2012. Cell Death Differ 19: 107-120, 2012.

34. Wang YX, Cai H, Jiang G, Zhou TB and Wu H: Silibinin inhibits proliferation, induces apoptosis and causes cell cycle arrest in human gastric cancer MGC803 cells via STAT3 pathway inhibition. Asian Pac J Cancer Prey 15: 6791-6798, 2014.

35. Heppner GH and Miller BE: Tumor heterogeneity: Biological implications and therapeutic consequences. Cancer Metastasis Rev 2: 5-23, 1983. 